\title{
Dealing with climate change in semi-arid Ghana: understanding intersectional perceptions and adaptation strategies of women farmers
}

\author{
Elaine T. Lawson (1D) Rahinatu Sidiki Alare - Abdul Rauf Zanya Salifu • \\ Mary Thompson-Hall
}

Published online: 5 February 2019

(C) The Author(s) 2019

\begin{abstract}
Climate change has diverse physical and socio-economic implications for communities in semi-arid areas. While several studies have sought to understand the underlying power relations that shape adaptive capacities of rural farmers, fewer studies have focused on unpacking the differences within the different social groups. In this paper, we present a case study based on women smallholder farmers from semi-arid Ghana. It explores their nuanced perceptions of climate variability and highlights how gender intersects with other identities, roles and responsibilities to influence adaptation strategies and barriers to adaptation in the semi-arid context. Farm-level data was collected from 103 women farmers using semistructured interviews, focus group discussions and key informant interviews. Rainfall patterns were perceived by the women farmers to be increasingly erratic and perceptions of average temperatures were that they are increasing. Adoption of adaptation strategies were influenced by socio-demographic factors such as age,
\end{abstract}

E. T. Lawson $(\bowtie)$ - A. R. Z. Salifu

Institute for Environment and Sanitation Studies (IESS), College of Basic and Applied Sciences, University of Ghana, P.O. LG 209, Legon, Accra, Ghana

e-mail: elaine_t@staff.ug.edu.gh

R. S. Alare

Faculty of Geosciences, P.O. Box 24, Navrongo, Ghana

M. Thompson-Hall

International START Secretariat, 1440 G Street NW,

Washington, DC 20009, USA marital and residential status, which also influenced decision-making and power dynamics within the household. The paper highlighted the complex relationships that mediate women farmers' access to resources and influence their vulnerability to climate variability and change. Highlighting the intra-gender differences that shaped the adaptation options and adaptive capacity is a prerequisite for proper adaptation policy planning and targeting.

Keywords Adaptation - Adaptive capacity - Climate variability and change $\cdot$ Farmers $\cdot$ Ghana $\cdot$ Perceptions

\section{Introduction}

The impacts of a changing climate on the lives and livelihoods of the global poor have become increasingly clear. These impacts are expected to disproportionately affect smallholder farmers in the semi-arid areas of Africa (Niang et al. 2014). Due to differences in sensitivities people will experience the impacts climate change differently. Key climatic impacts in semi-arid areas include increasing temperatures, dry spells, changes in timing of the onset and ending of rainy seasons and changes in lengths of crop growing periods. These changes will affect agricultural production and threaten household food security (Ogra and Badola 2015; Sarr et al. 2015). While many rural households have long adapted to environmental 
change, the rapidness and duration of current climate variability and change erodes opportunities to adjust to climate risks.

Over the years, most climate change research has focused on biophysical impacts, often to the detriment of understanding who is most affected by these impacts as well as understanding the combination of factors that may amplify risk during climate stress. This has left critical gaps regarding (i) how differences in sensitivities and adaptive capacities come about, (ii) how they are sustained and (iii) their implications for resilience in dynamic systems (Thompson-Hall et al. 2016). A comprehensive and holistic understanding of adaptation processes will therefore require an analysis of climate impacts from vulnerability and adaptive capacity lenses.

In this study, we focus on unpacking the different identities of women small scale farmers in semi-arid Ghana and on identifying the factors that influence their adaptation strategies. This is based on the premise that current research into the intra-gender differences shaping adaptive capacities to climate change is scanty (Ravera et al. 2016), and that there is a lack of empirical evidence on women's vulnerability (Arora-Jonsson 2011). Hence, we seek to understand how different groups of women farmers perceive climate variability and change as well as to understand their choices of adaptation options. The paper presents different voices which should be taken into consideration when decisions are made regarding climate change and development interventions (Baptiste and Kinlocke 2016; Carr 2008). By focusing on women's experiences, we complement existing research on climate change and livelihoods in the predominantly agrarian areas of the semi-arid regions of Ghana.

\section{Unpacking the intersection of social relations and adaptive behaviour}

Climate change vulnerability studies have shown that the determinants of vulnerability and adaptive capacities of men and women are gendered and mediated through socio-cultural, economic, and political structures and processes (Carr and Thompson 2014). According to Baptiste and Kinlocke (2016) the most vulnerable can be grouped based on several sociodemographic variables including gender, class, education, access to assets and social networks. Women have often been portrayed as being among the most vulnerable victims of climate change because of their higher dependence on natural resources and higher poverty rates (Arora-Jonsson 2011; Mainlay and Tan 2012). However, authors such as Arora-Jonsson (2011) have emphasised that whilst it is important to draw attention to the challenges women face in adapting to climate change and other climate related risks, simplistic and polarised representations of men and women rather lead to presenting women as a group of homogeneous "passive victims." Recent critiques from feminist political ecology perspectives have also questioned the soundness of the binary male-female view of gender in climate change studies which often underplay power relations which are frequently mediated at the household level and vary with geographical location (Ravera et al. 2016), and are determined by a host of other social markers like age, income, and ethnicity (Arora-Jonsson 2011).

These have resulted in several framings on the vulnerability of women due to their position in social hierarchy. Perceptions of women, especially from developing countries, based on their socially-constructed roles such as carers and provisioners are often as poor, subordinate and lacking the agency to develop resilience to climate impacts (MacGregor 2010). While such studies have fostered a broader understanding of gender and climate change, methodologically, they lack rigour (Arora-Jonsson 2011). Postmodern gender studies have also challenged the assumption of universality in gender studies and interrogate groupings of "females" and "males" based on other social identities (Arora-Jonsson 2011; Ravera et al. 2016; Thompson-Hall et al. 2016). Further, detracting from the range of vulnerabilities and challenges among different identities of both males and females may result in interventions that may inadvertently heighten the risk faced by these groups at the community level (Carr and Thompson 2014).

Building on this body of work, recent literature has focused on the socially differentiated vulnerability and adaptation of different men and women based on classes and social groupings (Rao et al. 2017; Ravera et al. 2016). For instance, Ravera et al. (2016) presents evidence from India of how multiple factors and identities intersect to differentially "influence farmers' choices on the range of adaptation options [and on how] roles, responsibilities and power dynamics are renegotiated within the household and the community, 
(un)empowering women" (Ravera et al. 2016). Van Aelst and Holvoet (2016) also found out that though a less important factor in the case of men, marital status of women was central in determining her access to adaptive strategies in Tanzania. In some cases, women organized themselves to increase their collective agency and decrease common vulnerabilities by mobilising their networks and social capital to prepare and respond to climate risks (Reed 2017). Such social infrastructure including collective action, social capital, knowledge sharing and social learning, and community initiated, or traditional responses are almost totally ignored (Reed 2017).

Dzah (2011, p.vii) advocates for an analysis that brings into the discussion the "intersection of social relations and identities that could present a more nuanced understanding of adaptive behaviour in a particular context". This way people and communities can express and experience their own capacity because it creates a pathway of analysis enabling "agency across and beyond social categories" (Kaijser and Kronsell 2014, p. 417).

\section{Materials and methods}

The study was carried in the Lawra and Nandom districts of the Upper West Region of Ghana, which are classified as semi-arid, and are located in the Guinea-Savannah agro-ecological zone (Fig. 1). It covers a land area of 527.37 square kilometres constituting about $2.8 \%$ of the region's total land area, which is estimated at 18,476 square kilometres (GSS 2014). The region is bordered by Burkina Faso to the north, the Northern Region to the south, Upper East Region to the east, and Côte D'Ivoire to the west. It has a unimodal rainfall pattern which starts from late May to early September (Nyantakyi-Frimpong and Bezner-Kerr 2015) and mean temperatures ranging from 27 to $36^{\circ} \mathrm{C}$ (GSS 2014).

Crop production and livestock rearing are the main economic activities in the districts, with $80 \%$ of the farmers being subsistence farmers (GSS 2014). Agriculture is mainly rainfed and is continuously threatened by both climatic and non-climatic stressors (Ahmed et al. 2016), that affect household food security and wellbeing (Yiran and Stringer 2016). Stressors such as climate variability, land degradation, water scarcity, unsustainable farming practices, poverty and post-independence political neglect have contributed to the current vulnerabilities faced by smallholder farmers in semi-arid Ghana (Al-hassan and Diao 2007; Nyantakyi-Frimpong and Bezner-Kerr 2015). In relation to gender, traditional patriarchal roles have favoured men and promoted structural inequalities among women in terms of decision making, access to and control over land for agricultural activities and the ability to engage in more productive activities compared to their male counterparts (Ahmed et al. 2016; Nyantakyi-Frimpong and Bezner-Kerr 2015).

A multistage sampling technique was used to gather primary data for the study. First of all the Upper West Region was purposely selected based on the region's increasing vulnerability to climate change and variability, coupled with the high incidence of poverty (Ahmed et al. 2016; Nyantakyi-Frimpong and BeznerKerr 2015; Rademacher-schulz et al. 2014). Second, a simple random sampling technique was used to select Lawra and Nandom districts out of eleven districts in the region. Two communities were also randomly selected from each district (Tolibiri and Kasalgre communities in Lawra district, Goziri and Ketuo in Nandom district) out of 54 and 62 communities in the Lawra and Nandom districts respectively.

A mixed method approach was used for this study consisting of a household semi structured interviews ( $n=103$ women), four focus group discussions (FGDs) and five key informant interviews. The convenience sampling technique was used to obtain the respondents of the questionnaire survey as used by Lawson et al. (2016). A sample was determined based on the availability, accessibility and readiness of target respondents to participate in the survey (Marshal 1996; Frey et al. 2000). This technique was necessary because it was not possible to obtain a sample frame for the target respondents in the study areas.

Semi-structured interview guides were used to collect both qualitative and quantitative data at the household level. Information on the socio-economic status of women farmers, perceptions on a changing climate and coping and adaptation strategies adopted by farmers in response to drivers of vulnerability was collected. In all 103 women farmers participated in the study and effort was taken to include women of different ages, economic and social backgrounds, marital status as well as migrant status. The FGDs gave more insights to the coping strategies of different 


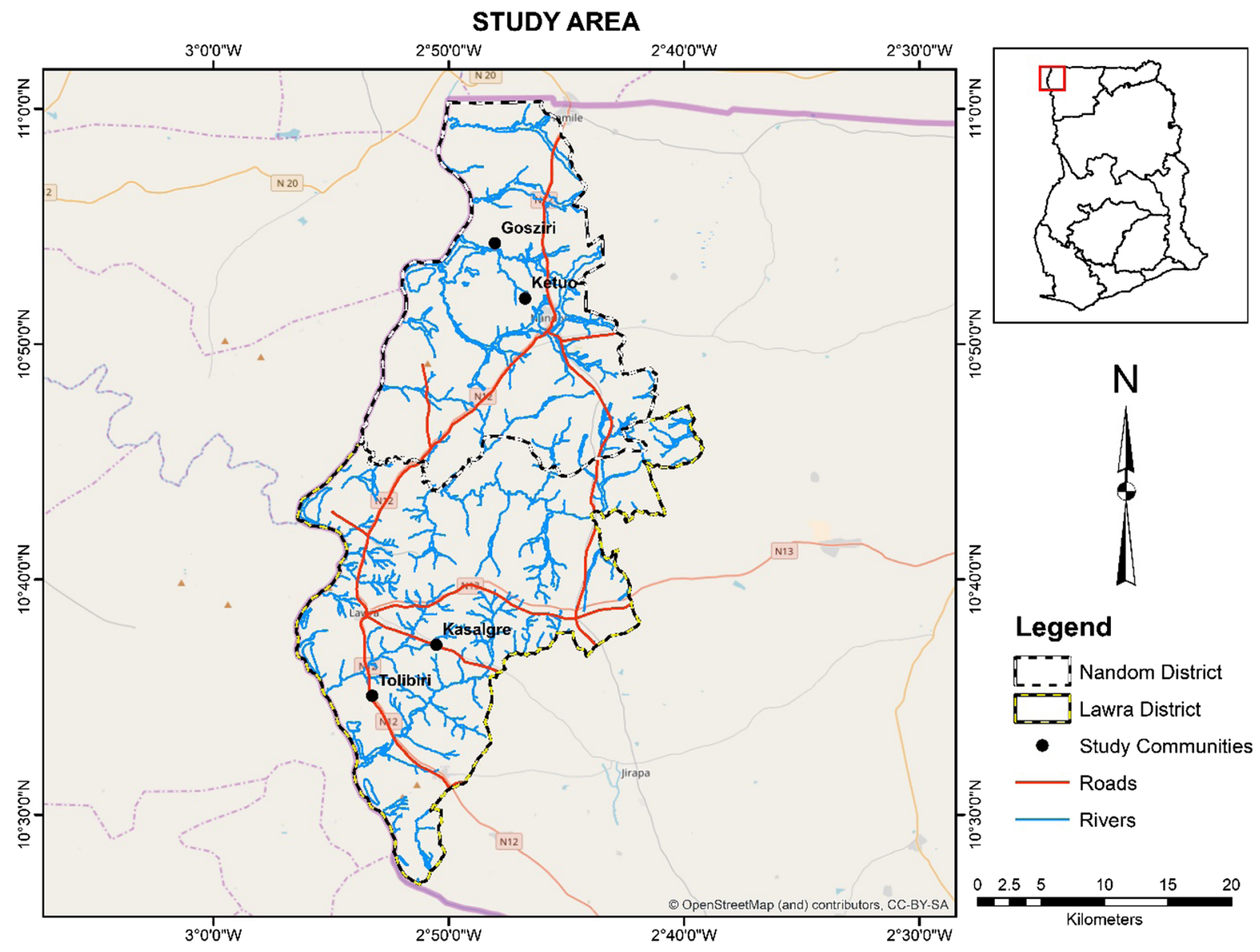

Fig. 1 Map of study area

women farmers and factors hindering successful adaptation strategies. Hence the methods used were largely descriptive in nature as we focused more the reasons behind actions taken. The qualitative design also sought to relate their experiences and to understand the socio-cultural milieu in which women farmers operated. The FGDs and the interviews were undertaken by a team of researchers and field assistants who understood the Dagaare language widely spoken in the study areas.

Observed data from the Ghana Meteorological Agency (GMet) was used as a comparison for the farmers' information collected on farmers' perception of a changing climate. The district temperature and rainfall data (1984-2014) from the closest weather station (Babile Community) was obtained from GMet. The data was first prepared, and the time series analysed in in excel. However, the observed data for both rainfall and temperature was only about $65 \%$ complete according GMet. The poor quality of the data obtained affected the extent to which conclusions could be made. The survey data was analysed using descriptive statistics in Statistical Package for Social Science (SPSS) Version 21 and data presented as means and frequencies. FGDs were recorded, transcribed and then translated from the Dagaare language into English by a translator who was part of the research team. The transcripts were then reviewed to ensure accuracy and consistency. To assess factors that influenced the adaptation strategies of women farmers, a content analysis of the transcripts of both young and elderly women were carried out and key themes developed. The results were then graphically presented. 


\section{Results}

The research findings are organized under three broad themes: (1) the perceptions of climate variability and change (2) adoption of adaptation strategies to climate change and variability; and (3) barriers to climate change adaptation.

Household and demographic information

Age, marital status and migrant status have been identified as significant social factors in the case study areas (Nyantakyi-Frimpong 2017; Rao et al. 2017). They influence the extent of access to and ownership of land, the most important economic and natural resource on which survival of most households depends.

A total of 103 women farmers participated in the study. The mean age was 46.2 years and most of the farmers $(58.5 \%)$ were $40-59$ years, with $17 \%$ being 60 years and older. Majority of the respondents $(82.1 \%)$ had no formal education and $11.3 \%$ of the respondents had primary education, with $6.6 \%$ completing senior high school. In addition, $66 \%$ were married while $31.2 \%$ and $2.8 \%$ were widowed and single respectively. Ethnicity followed a fairly homogenous pattern, with $99.1 \%$ of the women being from the Dagaaba ethnic group and the remaining $0.9 \%$ being from the Waala ethnic group. Access to farmland was by marriage or kinship as $89.6 \%$ of the farmers did not own lands and had access to farmlands by borrowing from their husbands or relatives. Thirty percent earned less than $\mathrm{Gh} \phi 300.00,58.5 \%$ earned between $\mathrm{Gh} \phi 300.00$ and $\mathrm{Gh} \phi 600.00$ and $4.7 \%$ between $\mathrm{Gh} \varnothing 400.00$ and $\mathrm{Gh} \phi 600.00$.

\section{Perceptions of climate variability and change}

With farmers in semi-arid areas already in a heightened position of vulnerability due to reliance on rainfed agriculture and natural resources we sought to understand their perceptions of climate variability and change. These perceptions were then compared with data from the Ghana Meteorological Agency (GMet). Many farmers perceived a change in temperature, rainfall patterns and the frequency of dry spells.

Temperatures were perceived to have increased (Fig. 2) and were seen as a source of stress on groundnut production as respondents linked this with several challenges such as crop failure due to withering and drying of crops, poor germination, pest and disease infestation (especially from aflatoxins), and physical difficulties of working on farm. A 65-yearold woman (Kalsagre-Lawra) mentioned during the FGDs that “... temperatures are very high compared to two or three decades ago, and when I go to my farm on a hot day I cannot work because I will become sick..."

Respondents' perception on rainfall shows that a decreasing trend was perceived as being the norm, with those married, people who were born in the communities) and those in the 20-30 years and 41-60 years age bracket more likely to believe that the rainfall had become more erratic (Fig. 3).

Usually, when the rains come and we sow our seeds, by the time our seeds start to germinate, the rain ceases. These bring so much heat and our seeds are being scorched by the sun. Sometimes too, we can't immediately harvest our groundnuts during harvest periods because the soils are often not moist and loose enough to pull out the groundnuts due to insufficient rainfall. (A 54-year-old woman from Ketuo-Nandom)

Truly the climate is changing because things are not the same as they were before. In the past, we had regular rainfall patterns- the rains fell by May and ended in October. We are currently not experiencing the early rainfall. The rains start late, are erratic and end early with accompanying heat.

\section{(A 61-year-old woman from Goziri-Nandom)}

Drought was identified as one of the main threats to agriculture in the area, however drought occurrence was perceived to have become intermittent in the study areas. Dry spells were occasional (Fig. 4). Increasing temperature and erratic rainfall have been associated with poor seed formation, wilting and crop failure, thereby threatening household food security (Fig. 4)

Historical annual mean rainfall and temperature data obtained from GMet for the study area for the past 30 years (1984-2014) revealed a trend in climate variability. The Lawra district experienced lower rainfalls in 1984 (764.1 mm), 1990 (642 mm), 2004 $(565.5 \mathrm{~mm})$ and $2008(549.4 \mathrm{~mm})$. However, the highest rainfall was recorded in 1999 (1265 mm) (Fig. 5). Similarly, temperature showed some 
Fig. 2 Perception of temperature over the last 2-3 decades

Fig. 3 Perception of changes in rainfall pattern over the past 2-3 decades
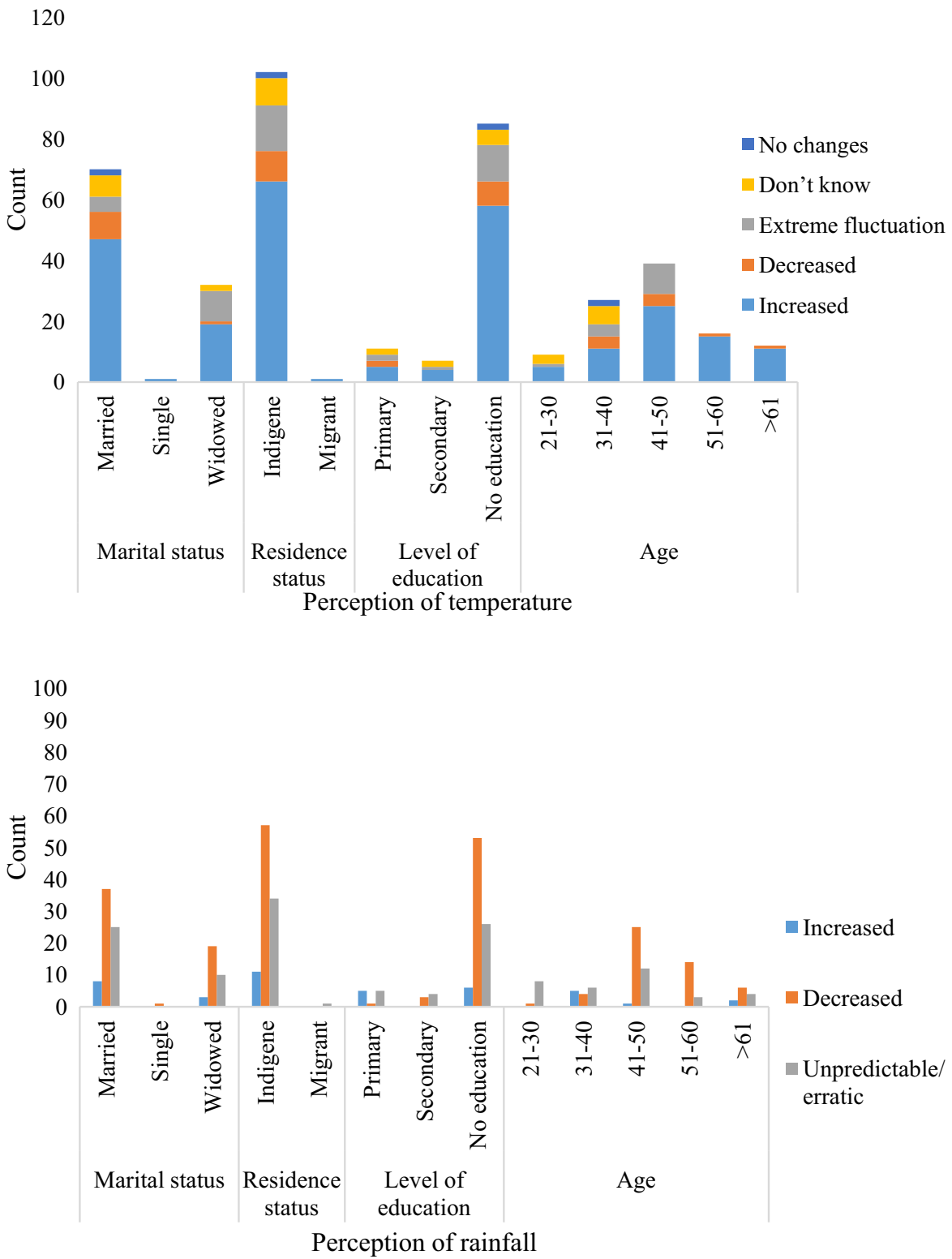

variability with slight increases since 1984. Especially since 1999, temperature values have remained higher than the long term average (Nyantakyi-Frimpong and Bezner-Kerr 2015).

Adoption of adaptation strategies to climate change and variability

Women farmers responded to the difficulties caused by erratic rainfall and increasing temperature in several ways. These include knowledge of the use of stored grains, changing sowing and harvesting times, dry season gardening, soil conservation and growing new crops were largely obtained through individual experiences or from relatives and friends. According to Codjoe et al. (2013), most women farmers were already managing climate risk. The most adopted practices were changing planting dates $(100 \%)$, mixed farming (95.3\%), intercropping (94.3\%), planting early maturing varieties $(76.4 \%)$, composting $(62.3 \%)$ and off-farm activities $(42.5 \%)$. The least adopted practices among female farmers were 
Fig. 4 Perception of droughts and dry spells during farming season

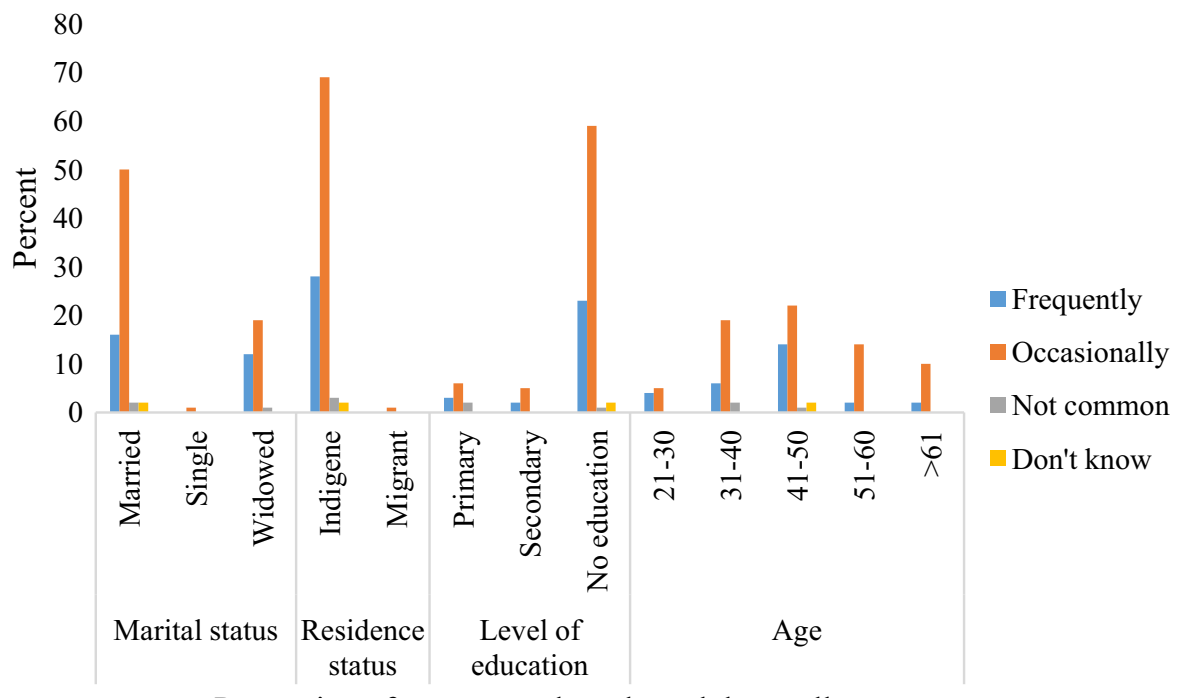

Perception of occurence drought and dry spells
Fig. 5 Average rainfall variability, Babile station, Upper West Region, Ghana

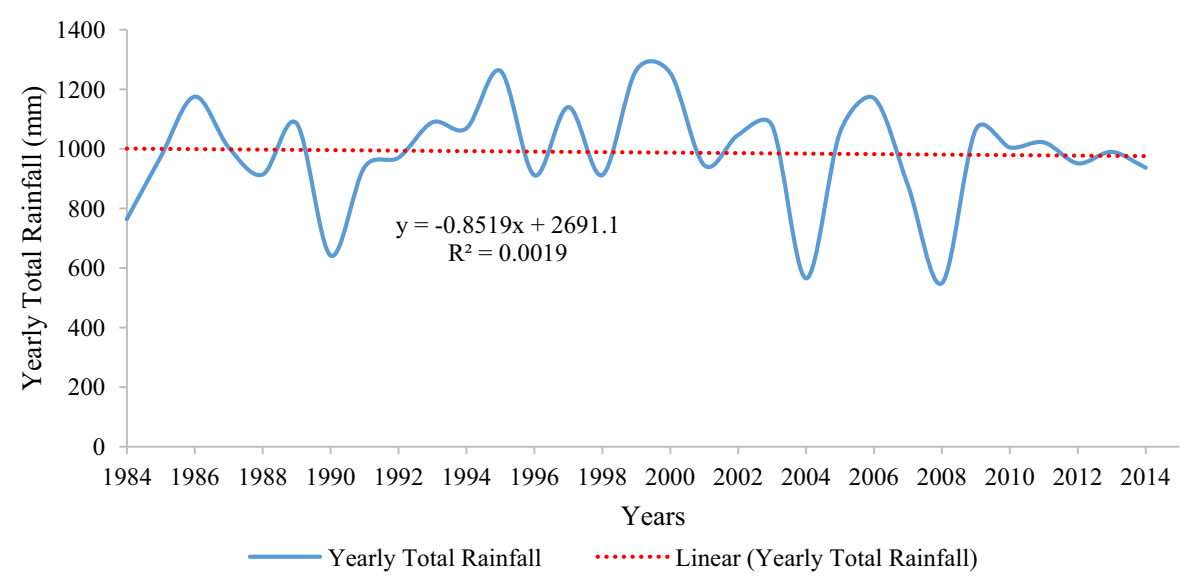

seasonal migration (2.8\%), chemical fertilisers $(1.9 \%)$. Water harvesting techniques, insurance and irrigation were not adopted. Further analyses showed that more married women, between the ages of 31-50, those born in the area were more adept at adopting adaptation strategies (Table 1).

Hesselberg and Yaro (2006) and Apata (2011) report that mixed farming is an important adaptation strategy for most farmers in Africa. Similarly, in our research mixed farming is an important source of additional income for families. Two main socioeconomic strategies adopted to generate additional income included petty trading and out-migration. Migration was occasionally adopted by relatively younger women between 20 and 30 years. Most of the agro-biodiversity strategies were adopted by married women aged 20-50 years. Despite living in a water scarce environment, strategies that involved conservation of water were not adopted. The use of agrochemical inputs and irrigation schemes is low among all the socially differentiated groups of women farmers. The also participated in alternative livelihoods such as trading and processing to support themselves and their households (Lolig et al. 2014). Marital status influenced the choice of adaptation strategy and the commonly adopted ones were switching to early maturing varieties, crop farming and livestock, changing planting dates and the use of compost. This is likely because most married women had better access to information, land and agricultural input through their husbands and they shared this information among themselves, which enhanced their 
Table 1 Adaptation strategies selected by women farmers in study areas

\begin{tabular}{|c|c|c|c|c|c|c|c|c|c|c|}
\hline & $\begin{array}{l}\text { Early } \\
\text { maturing } \\
\text { varieties } \\
\%\end{array}$ & $\begin{array}{l}\text { Crop/ } \\
\text { livestock } \\
\text { farming } \\
\%\end{array}$ & $\begin{array}{l}\text { Planting } \\
\text { different } \\
\text { crops } \\
\%\end{array}$ & $\begin{array}{l}\text { Changing } \\
\text { planting } \\
\text { dates } \\
\%\end{array}$ & $\begin{array}{l}\text { Compost } \\
\%\end{array}$ & $\begin{array}{l}\text { Tillage } \\
\%\end{array}$ & $\begin{array}{l}\text { Drought } \\
\text { tolerant } \\
\text { varieties } \\
\%\end{array}$ & $\begin{array}{l}\text { Chemicals/ } \\
\text { fertilizers/ } \\
\text { pesticides } \\
\%\end{array}$ & $\begin{array}{l}\text { Off } \\
\text { farm } \\
\%\end{array}$ & $\begin{array}{l}\text { Migration } \\
\%\end{array}$ \\
\hline \multicolumn{11}{|l|}{ Marital status } \\
\hline Married & 48.1 & 66 & 64.3 & 66 & 45.3 & 12.3 & 4.7 & 1.9 & 20.1 & 2.8 \\
\hline Single & 1.9 & 1.9 & 2.8 & 2.8 & 1.9 & 0.9 & 0 & 0 & 1.9 & 0 \\
\hline Widowed & 26.4 & 27.4 & 27.4 & 31.1 & 15.1 & 7.5 & 0 & 0 & 22.2 & 0 \\
\hline \multicolumn{11}{|l|}{ Age } \\
\hline $21-30$ & 4.7 & 8.5 & 9.4 & 9.5 & 4.7 & 3.9 & 3.4 & & 5.8 & 2.8 \\
\hline $31-40$ & 21.6 & 24.3 & 24.4 & 25.4 & 16.9 & 2.8 & 0.4 & 1.9 & 11.5 & 0 \\
\hline $41-50$ & 26.3 & 37.4 & 35.8 & 37.3 & 25.4 & 7.1 & 0.9 & & 16.4 & 0 \\
\hline $51-60$ & 16.4 & 16 & 16.3 & 16.6 & 13.5 & 5.9 & 0 & & 8.7 & 0 \\
\hline$>61$ & 7.4 & 9.3 & 8.6 & 11.2 & 1.8 & 0.9 & 0 & & 1 & 0 \\
\hline \multicolumn{11}{|c|}{ Residential status } \\
\hline Indigene & 75.5 & 94.3 & 93.4 & 99.1 & 62.3 & 20.8 & 4.7 & 1.9 & 43.3 & 2.8 \\
\hline Migrant & 0.9 & 0.9 & 1.1 & 0.9 & 0 & 0 & 0 & 0 & 0 & 0 \\
\hline \multicolumn{11}{|l|}{ Education } \\
\hline Primary & 10.7 & 10.7 & 10.6 & 10.7 & 9.7 & 0 & 0 & 0 & 7.9 & 0 \\
\hline Secondary & 4.9 & 6.8 & 6.8 & 6.8 & 4.9 & 4.9 & 1.9 & 1.9 & 3 & 2.9 \\
\hline $\begin{array}{l}\text { No formal } \\
\text { education }\end{array}$ & 60.2 & 77.7 & 76.7 & 82.5 & 46.6 & 14.6 & 2.9 & 0 & 31.7 & 0 \\
\hline
\end{tabular}

adoption to these adaptation strategies. Changing planting dates was widely adopted by farmers based on their own experiences with changing weather patterns. A 55-year-old woman from Kalsagre noted that:

Past experiences have taught us not to quickly sow when the first rains come. It comes and never rain again till the mid growing season. We fear taking such risk again. distil

Barriers to climate change adaptation

In the FGDs, age and cultural practices were mentioned to be barriers to adaptation among groundnut farmers. Older farmers were unable to adopt practices such as stone ridging and row planting due its labour requirements. Culturally, women were prevented from learning how to make energy-saving cooking stoves for a living because some men believed women would usurp their positions as household heads if they became financially independent. Barriers to the adoption of adaptation strategies were further qualitatively explored based on age and the type of capitals or assets accessible to the women farmers. The age groupings were re-ordered to highlight economically active women farmers between 25 and 66 years. Responses were also organised into social, physical and financial capitals. All age groups had social ties and received some form of support from institutions (Table 2). Older farmers had low literacy rates and informal skills and less mobility. While younger farmers had access to financial capital through participation of village savings and loans association (VSLA) and additional livelihood activities, remittances were higher for older farmers.

A key barrier to adaption among women farmers was land access and ownership. Women who had access to land were able to improve or optimize their livelihoods (Onta and Resurreccion 2011). Land ownership was low especially for young farmers, widowed and single farmers (Fig. 6). Women culturally could not inherit land from their fathers. Married women could receive land from their husbands or family members. Some farmers borrowed land from their relatives for farming, with a few others obtaining their farmlands from gifts and leasehold arrangements. 
Table 2 Overcoming barriers to climate change adaptation

\begin{tabular}{|c|c|c|c|c|c|c|c|}
\hline Capital & Factors & $\begin{array}{l}\text { Under } \\
25 \text { years } \\
(\mathrm{n}=1)\end{array}$ & $\begin{array}{l}25-35 \\
\text { years } \\
(n=21)\end{array}$ & $\begin{array}{l}36-45 \\
\text { years } \\
(n=32)\end{array}$ & $\begin{array}{l}46-55 \\
\text { years } \\
(n=32)\end{array}$ & $\begin{array}{l}56-65 \\
\text { years } \\
(n=13)\end{array}$ & $\begin{array}{l}>66 \\
\text { years } \\
(n=7)\end{array}$ \\
\hline \multirow[t]{3}{*}{ Social capital } & Membership in organisations & 0 & 10.4 & 18.9 & 23.6 & 9.4 & 4.7 \\
\hline & Support from relatives & 0 & 10.4 & 8.5 & 14.2 & 8.5 & 4.7 \\
\hline & Support from Government/NGOs & 0 & 10.4 & 16 & 19.8 & 7.5 & 2.8 \\
\hline \multirow[t]{3}{*}{ Human capital } & Formal literacy & 0 & 7.5 & 0.9 & 0.9 & 0 & 0 \\
\hline & Informal skills & 0.9 & 5.7 & 0.9 & 3.8 & 0 & 0 \\
\hline & Migration & 0 & 2.8 & 0 & 0 & 0 & 0 \\
\hline \multirow[t]{3}{*}{ Financial capital } & VSLA & 0.9 & 12.3 & 23.6 & 17.9 & 4.7 & 2.8 \\
\hline & Income from additional livelihoods & 0.9 & 10.4 & 15.1 & 12.3 & 3.8 & 0 \\
\hline & Remittances & 0 & 2.8 & 5.7 & 8.5 & 6.6 & 4.7 \\
\hline \multirow[t]{4}{*}{ Physical capital } & Aid from NGOs & 0 & 0.9 & 2.8 & 5.7 & 3.8 & 0 \\
\hline & Information & 0.9 & 11.3 & 20.8 & 11.3 & 7.5 & 0 \\
\hline & Improved seeds & 0.9 & 8.5 & 17.9 & 9.4 & 10.4 & 0 \\
\hline & Machinery & 0 & 0 & 0 & 5.7 & 0 & 0 \\
\hline Natural capital & Land ownership & 0.9 & 2.8 & 2.8 & 0 & 2.8 & 0 \\
\hline
\end{tabular}

Farmers born in the community had better access to land.

\section{Discussion}

Future projections of climate change in West Africa are uncertain, particularly with respect to changes in precipitation (Padgham et al. 2015). However, a delay in the onset of rainfall, a reduction in rainfall during the onset period, an increase in rainfall in the latter part of the season and a reduction in the overall length of the rainy season have been projected, for Ghana (MESTI 2013; Padgham et al. 2015). Most of the farmers perceived that rainfall had become more variable, and that temperatures were increasing. This was corroborated by the observed rainfall and temperature data collected from GMet and NyantakyiFrimpong and Bezner-Kerr (2015). Consistent with findings from Nyantakyi-Frimpong and Bezner-Kerr 2015 and Sarr et al. (2015), the farmers noted the erratic nature of current rainfall patterns in the district
Fig. 6 Women farmers and land ownership

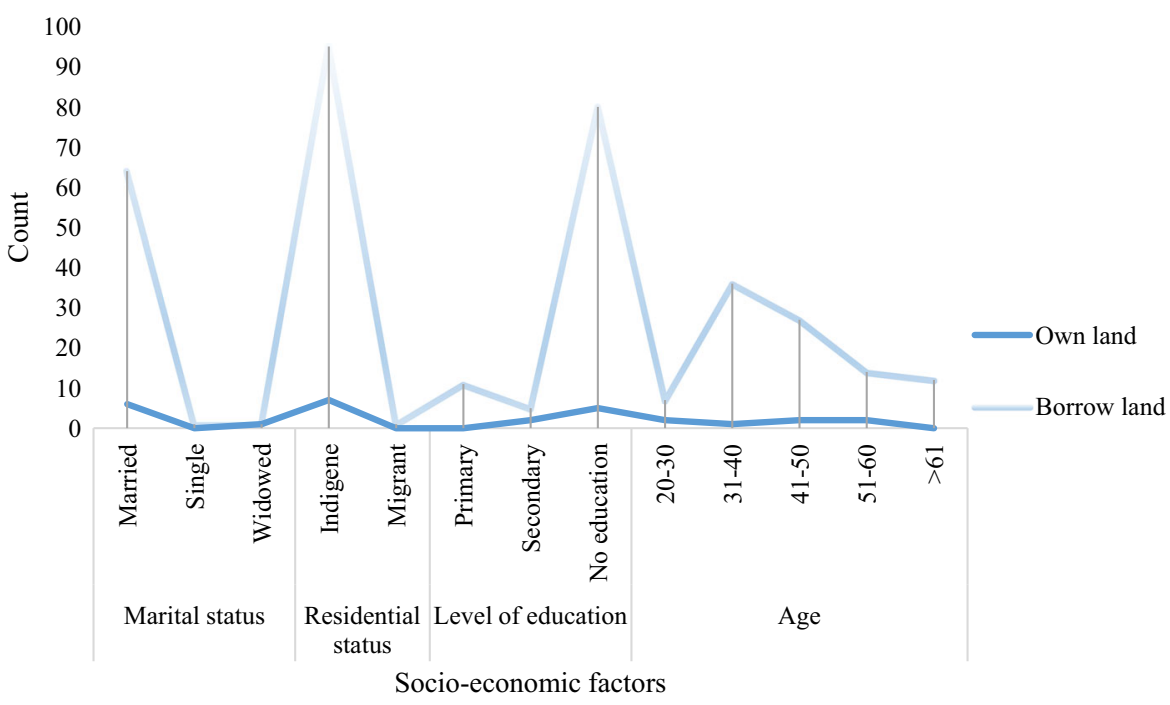


often manifested as false starts or dry spells, which threaten crop production. The perceived increase in temperature was also consistent with findings from EPA (2015), that all agro-ecological zones had experienced increases in temperature since 1960.

This study sought to identify how the interplay of multiple identities, such as age, marital status and residential status of women farmers shaped differentiated vulnerabilities to the impacts of variability and climate change in semi-arid Ghana. According to studies such as Deressa et al. (2011), age is a key determinant in how people perceived changes in climate. In this study, the women farmers between the ages of $31-50$ years perceived more changes in temperature and rainfall compared to the other age groups. They also represented the most economically active group. The differences in these perceptions also influenced the varied responses adopted to help women farmers adapt. Most of the adaptation strategies were autonomous and were homogeneously adopted, such as strategies in response to the erratic rainfall (changing planting dates, early maturing varieties and intercropping), livelihood risk management (mixed farming, seasonal migration and off-farm jobs) and soil fertility enhancement (compost and chemical fertiliser).

Access to land is critical to adaptation in the study areas as it is linked to vulnerability, livelihoods and food security. Earlier research has outlined the need for land reforms to ensure women's improved access to land (Yaro 2010; Ahmed et al. 2016; NyantakyiFrimpong and Bezner-Kerr 2015; Rademacher-schulz et al. 2014; Rao et al. 2017). In a region where agriculture is the main source of food and income, land ownership is critical to social wellbeing (Akologo and Guri, 2016). Most of the women farmers could not own land, which affected their willingness to adopt innovative adaptation practices. They acquired land through insecure means (such as borrowing from relatives). Age, marital status and residential status influenced access to land for women farmers. Farmers who were born and raised in the area had better access to land as compared to migrant women farmers. Older farmers were more likely than younger farmers to have tenure security, and married women (especially those with sons) had better access to land. Single, young, women were less likely to implement innovative adaptation strategies, and were more likely to migrate.
Gendered roles, responsibilities, and rights over resources were clearly established at the household level (Nyantakyi-Frimpong and Bezner-Kerr 2015). Due to limited work opportunities in the communities, young women often migrated to southern Ghana in search of economic opportunities. This trend has been attributed to the wide structural and developmental gap between the northern and southern Ghana as a result of colonial policies that deliberately discriminated against the northern regions (Ahmed et al. 2016; Nyantakyi-Frimpong and Bezner-Kerr 2015). Single women may permanently migrate and married women whose husbands lived in the communities sometimes migrated seasonally during the off-farming season. During the FGDs, some married women revealed that although their husbands could not provide all their basic needs (such as cooking utensils, cloth and other household items), they also prevented them from travelling to other parts of the country to work. This they believed was because their husbands wanted them to work on their farms. Hence marriage restricted the married the women's mobility, even when this could enhance their adaptive capacities. Notwithstanding such restrictions, women in these communities are engaged in additional livelihoods such as groundnut farming, the sale of locally manufactured drinks such as Pito, Shea butter and groundnut processing, basket weaving and petty trading for subsistence. More widowed women farmers engaged in off-farm activities to supplement their income. This could be related to their poorer access to farm land and disproportionally increases their overall work burdens relative to the returns.

Water harvesting, use of chemical fertilisers and irrigation were the least adopted practices. Water harvesting and irrigation require substantial technical knowledge as well as investment. Since most of the women could not own land they were reluctant to invest heavily in lands that could be taken from them. As highlighted in this paper, majority of women had no land tenure rights to control, invest or make useful decisions about the lands. While the widowed farmers could have access to farmlands through their sons, the married had access to borrowed lands facilitated by their husbands. A female farmer inheriting portions of their father's land was rare. As 36-year-old woman from Tolibiri-Lawra mentioned: 
... some husbands or landowners will take back their lands when they realised you have improved the land fertility. So the lands on which we farm are not secured. It can be taken away from you at any time by the owners. Some women may also lose the land they cultivate on after the demise of their husbands.

When factors for non-adoption were further classified to the various capitals essential for sustainable livelihoods and across all ages, there was enough evidence that women farmers lacked both natural and human capital. Low literacy rates, informal skills and lack of access to land cumulatively constrained their adaptation strategies. However, the presence of strong social ties, access to village savings and loans association (VSLA) and the ability to diversify their livelihoods contributed to managing risk. Bryan et al. (2009) and (Kithiia (2011) reported that financial barriers are further key barriers that limit adoption of useful strategies. They include inadequate capital, the absence of or poor access to credit services, finances and grants. Financial barriers hamper access to fertiliser and improved crop varieties.

Residential status also influenced adaptation options. Farmers who were born and had lived most of their lives in the communities were much more familiar with the climatic conditions in the area as compared to the migrants, for that reason they are able to more easily formulate adaptation strategies. Our study shows that women farmers who are nonmigrants appear to have adapted better to recent manifestations of weather extremes than those who had migrated to the area. They also had a relatively better access to resources.

According to Fatuase and Ajibefun (2014) formal education to senior high and tertiary levels influenced adaptation options. Low levels of education limit the ability of people to gain extra employment opportunities particularly in the non-farm sector (Minot et al. 2006). However, many of the women farmers had little or no formal education. This paper however advocates for improved extension education to improved intensity of use of adaptation options (Di Falco et al. 2011; Fatuase and Ajibefun 2014). Respondents who gained access to information on farming issues engaged in adaptation strategies. Anley et al. (2007) found that in Haiti, farmers who have good access to extension services were expected to adopt better technologies.
On the other hand, some adaptation studies have stated that extension services were not an important factor affecting the adoption of adaptation practices (Davis et al. 2013). In this study not all the farmers had access to extension services likely because extension services concentrate on cash crops, an area dominated by men (Britwum and Akorsu 2016). In addition, cultural norms will dictate the extent to which women farmers could access extension services. Finally, most of the women did not own television and radio sets. In households where these tools information were available the choice of frequencies was often regulated by the husband. In addition, women farmers' work burden limited their listenership.

\section{Conclusion}

A better understanding of the processes that shape women farmers' adaptation to climate change is critical for developing well-targeted adaptation policies. This paper has highlighted the complex relationships that mediate women farmers' access to resources and influence their vulnerability to climate variability and change. Adoption decisions are informed by their gendered positioning within the agricultural production systems of their respective communities (Britwum and Akorsu 2016). In semi-arid Ghana, most of the residents maintain livelihood strategies that include a combination of subsistence or small-scale agriculture, livestock rearing, seasonal or long-term migration, and localized natural resource extraction. While warming temperatures, erratic rainfall patterns and changing ecological systems present similar challenges to the different groups (Ogra and Badola 2015), the vulnerabilities, responses and decisionmaking abilities of these different individuals and groups in relation to climate change can be linked to social structures based on characteristics such as gender, socio-economic status, ethnicity, age, and physical context (Kaijser and Kronsell 2014). Women farmers' ability to adopt off-farm strategies such as petty trading in agricultural and consumable goods increase their resilience and their decision-making power at the household level, which is an indicator of empowerment (Wrigley-Asante 2011). Considering that many of the surveyed households consume most of what they produce, addressing inequities in access to land is likely to be an important strategy for 
reducing vulnerability and improving food security at the household level.

Women farmers are made up of categories that are not fixed but are dynamic, changeable, and interlinked (Lykke 2010). This paper has shown that many of the constraints and opportunities women face in the context of climate variability and change are shaped at the intersection of the responsibilities and expectations attached to a wide range of social differences which are constantly changing (Carr 2008). It has highlighted the intra-gender differences that shape the adoption of adaptation strategies, showing that women are not a homogenous group and even within the various socially differentiated groups generalisations cannot be made Adoption of adaptation strategies are influenced by socio-demographic factors such as age, level of education, and marital and migration status, which also influence decision-making and power dynamics and negotiation within the household. Patriarchal and socio-cultural norms increasingly shape how different groups of women cope with climatic impacts in different ways. Highlighting the intra-gender differences that shape the adaptation options and adaptive capacity to climate is a prerequisite for proper adaptation policy planning and targeting.

Acknowledgement This work was carried out with fieldwork assistance from the Adaptation at Scale in Semi-Arid Regions project (ASSAR). ASSAR is one of five research programs funded under the Collaborative Adaptation Research Initiative in Africa and Asia (CARIAA), with financial support from the UK Government's Department for International Development (DfID) and the International Development Research Centre (IDRC), Canada (107640-001).

\section{Compliance with ethical standards}

Ethical approval Ethical clearance to undertake study was sought from the University of Ghana under the Climate Change and Sustainable Development Programme. In the study area, the permission of gatekeepers (chiefs, individuals from relevant agencies or organizations, assembly men and others in authority) was sought before commencing this study.

Informed consent All respondents were informed of the nature of the study to get their consent before proceeding with the interview. Research participants were not exposed any risk of physical and psychological threat. Participation in the research was voluntary and respondents had the right to partake or not. They could even quit in the middle of participation without providing a justification for their actions. In this study however, none of the respondents declined from participation. Participants in the study were assured that the data would be used for academic research purposes only and would be handled properly to guarantee their safety and confidentiality.

Human and animal rights No animals were used/harmed in this study as the research did not involved animals.

Open Access This article is distributed under the terms of the Creative Commons Attribution 4.0 International License (http:// creativecommons.org/licenses/by/4.0/), which permits unrestricted use, distribution, and reproduction in any medium, provided you give appropriate credit to the original author(s) and the source, provide a link to the Creative Commons license, and indicate if changes were made.

\section{References}

Ahmed, A., Lawson, E. T., Mensah, A., Gordon, C., \& Padgham, J. (2016). Adaptation to climate change or non-climatic stressors in semi-arid regions? Evidence of gender differentiation in three agrarian districts of Ghana. Environmental Development, 20(2016), 45-58. https://doi.org/ 10.1016/j.envdev.2016.08.002.

Akologo, S. Z., \& Guri, B. Y. (2016). Unmasking land grabbing in Ghana: Restoring livelihoods; Paving the way for Sustainable Development Goals. A Report of CARITAS Ghana.

Al-hassan, R. M., \& Diao, X. (2007). Regional disparities in Ghana: Policy options and public investment. Ghana Strategy Support Program (GSSP) Background Paper No. GSSP 0002.

Anley, Y., Bogale, A., \& Haile-Gabriel, A. (2007). Adoption decision and use intensity of soil and water conservation measures by smallholder subsistence farmers in Dedo District, Western Ethiopia. Land Degradation and Devlopment, 18(3), 289-302. https://doi.org/10.1002/ldr.

Apata, T. G. (2011). Factors influencing the perception and choice of adaptation measures to climate change among farmers in Nigeria. Evidence from farm households in Southwest Nigeria. Environmental Economics, 2(4), 74-83.

Arora-Jonsson, S. (2011). Virtue and vulnerability: Discourses on women, gender and climate change. Global Environmental Change, 21(2), 744-751. https://doi.org/10.1016/j. gloenvcha.2011.01.005.

Baptiste, A. K., \& Kinlocke, R. (2016). Geoforum We are not all the same!: Comparative climate change vulnerabilities among fishers in Old Harbour Bay, Jamaica. Geoforum, 73(2016), 47-59. https://doi.org/10.1016/j.geoforum.2015. 05.006 .

Britwum, A. O., \& Akorsu A. D. (2016). Qualitative gender evaluation of agricultural intensification practices in northern Ghana. International Institute of Tropical Agriculture. Retrieved from https://cgspace.cgiar.org/ bitstream/handle/10568/78479/AR_gender_ghana_ dec2016.pdf?sequence=1. Accessed 12 Feb 2018.

Bryan, E., Deressa, T. T., Gbetibouo, G. A., \& Ringler, C. (2009). Adaptation to climate change in Ethiopia and South Africa: Options and constraints. Environmental Science \& 
Policy, 12(4), 413-426. https://doi.org/10.1016/j.envsci. 2008.11.002.

Carr, E. R. (2008). Men's crops and women's crops : The importance of gender to the understanding of agricultural and development outcomes in Ghana's Central Region. World Development, 36(5), 900-915. https://doi.org/10. 1016/j.worlddev.2007.05.009.

Carr, E. R., \& Thompson, M. C. (2014). Gender and climate change adaptation in agrarian settings. Geography Compass, 8(3), 182-197. https://doi.org/10.1111/gec3.12121.

Codjoe, F. N. Y., Ocansey, C. K., Boateng, D. O., \& Ofori, J. (2013). Climate change awareness and coping strategies of cocoa farmers in rural Ghana. Journal of Biology, Agriculture and Healthcare, 3(11), 19-29.

Davis, K., Nkonya, E., Kato, E., Mekonnen, D. A., Odendo, M., Miiro, R., et al. (2013). The impact of farmer field schools on agricultural productivity and poverty in East Africa. World Development, 40(2), 402-413.

Deressa, T. T., Hassan, R. M., \& Ringler, C. (2011). Perception of and adaptation to climate change by farmers in the Nile basin of Ethiopia. Journal of Agricultural Science, 149(1), 23-31. https://doi.org/10.1017/S0021859610000687.

Di Falco, S., Veronesi, M., \& Yesuf, M. (2011). Does adaptation to climate change provide food security? A micro-perspective from Ethiopia. American Journal of Agricultural Economics, 93(3), 829-846. https://doi.org/10.1093/ajae/ aar006.

Dzah, E. D. E. (2011). Gender dynamics of climate change in Ghana: An intersectional perspective. Erasmus University.

EPA. (2015). Ghana's Third National Communication Report to the UNFCCC 2015 Climate Change Report Ghana's Third National Communication Report to the UNFCCC. Accra, Ghana. Retrieved from http://unfccc.int/resource/docs/ natc/ghanc3.pdf. Accessed 1 Dec 2017.

Fatuase, A., \& Ajibefun, I. (2014). Perception and adaptation to climate change among farmers in selected communities of Ekiti State, Nigeria. Journal of Agricultural Faculty of Gaziosmanpasa University, 31(3), 101-114.

Frey, L. R., Carl, H. B., \& Gary, L. K. (2000). Investigating communication: An introduction to research methods (2nd ed.). Boston: Allyn and Bacon.

GSS. (2014). 2010 population and housing census: District analytical report, Lawra district. Accra, Ghana.

Hesselberg, J., \& Yaro, J. A. (2006). An assessment of the extent and causes of food insecurity in northern Ghana using a livelihood vulnerability framework. GeoJournal, 67(1), 41-55. https://doi.org/10.1007/s10708-006-9007-2.

Kaijser, A., \& Kronsell, A. (2014). Climate change through the lens of intersectionality. Environmental Politics, 23(3), 417-433. https://doi.org/10.1080/09644016.2013.835203.

Kithiia, J. (2011). Climate change risk responses in East African cities: Need, barriers and opportunities. Environmental Sustainability, 3(3), 176-180. https://doi.org/10.1016/j. cosust.2010.12.002.

Lawson, E. T., Ayivor, J. S., Ohemeng, F., \& Ntiamoa-Baidu, Y. (2016). Social determinants of a potential spillover of batborne viruses to humans in Ghana. International Journal of Biology, 8(2), 66-76. https://doi.org/10.5539/ijb.v8n2p66.

Lolig, V., Donkoh, S. A., Obeng, F. K., Gershon, I., Ansah, K., Jasaw, G. S., et al. (2014). Households' coping strategies in drought- and flood-prone communities in Northern Ghana. Journal of Disaster Research, 9(4), 543-553.

Lykke, N. (2010). Feminist studies: A guide to intersectional theory, methodology and writing (1st ed.). New York: Routledge Sociology. Retrieved from http://urn.kb.se/ resolve?urn=urn:nbn:se:liu:diva-50727. Accessed 1 Mar 2018

MacGregor, S. (2010). 'Gender and climate change': From impacts to discourses. Journal of the Indian Ocean Region, 6(2), 233-238. https://doi.org/10.1080/19480881.2010. 536669.

Mainlay, J., \& Tan, S. F. (2012). Mainstreaming gender and climate change in Nepal. IIED Climate Change Working Paper No. 2.

Marshal, M. N. (1996). Sampling for qualitative research. Family Practice, 13(6), 522-525.

MESTI. (2013). Ghana National Climate Change Policy. Ministry of Environment, Science, Technology and Innovation.

Minot, N., Epprecht, M., Anh, T. T. T., \& Trung, L. Q. (2006). Income diversification and poverty in the Northern Upland of Vietnam. Research No. 145. International Food Policy Research Institute, Washington, DC.

Niang, I., Ruppel, O. C., Abdrabo, M. A., Essel, A., Lennard, C., Padgham, J., \& Urquhart, P. (2014). Africa. In: V. R. Barros, C. B. Field, D. J. Dokken, M. D. Mastrandrea, K. J. Mach, T. E. Bilir, M. Chatterjee, K. L. Ebi, Y. O. Estrada, R. C. Genova, B. Girma, E. S. Kissel, A. N. Levy, S. MacCracken, P. R. Mastrandrea \& L. L. White (Eds.), Climate change 2014: Impacts, adaptation, and vulnerability. Part B: Regional aspects. Contribution of working group II to the fifth assessment report of the intergovernmental panel on climate change (pp. 1199-1265). Cambridge University Press, Cambridge.

Nyantakyi-Frimpong, H. (2017). Agricultural diversification and dietary diversity: A feminist political ecology of the everyday experiences of landless and smallholder households in northern Ghana. Geoforum, 86(2017), 63-75.

Nyantakyi-Frimpong, H., \& Bezner-Kerr, R. (2015). The relative importance of climate change in the context of multiple stressors in semi-arid Ghana. Global Environmental Change, 32(2015), 40-56. https://doi.org/10.1016/j. gloenvcha.2015.03.003.

Ogra, M. V., \& Badola, R. (2015). Gender and climate change in the Indian Himalayas : Global threats, local vulnerabilities, and livelihood diversification at the Nanda Devi Biosphere Reserve. Earth System Dynamics, 6(2), 505-523. https:// doi.org/10.5194/esd-6-505-2015.

Onta, N., \& Resurreccion, B. P. (2011). The role of gender and caste in climate adaptation strategies in Nepal. Mountain Research and Development, 31(4), 351-356. https://doi. org/10.1659/MRD-JOURNAL-D-10-00085.1.

Padgham, J., Abubakari, A., Ayivor, J., Dietrich, K., FosuMensah, B., Gordon, C., Habtezion, S., Lawson, E., Mensah, A., Nukpezah, D., Ofori, B., Piltz, S., Sidibe, A., Sissoko, M., Totin, E., \& Traore, S. (2015). Vulnerability and adaptation to climate change in the semi-arid regions of West Africa. ASSAR working paper, ASSAR PMU, South Africa. Retrieved from: http://www.assar.uct.ac.za/ sites/default/files/image_tool/images/138/RDS_reports/ 
West_africa/West\%20Africa\%20Regional\%

20Diagnostic\%20Study.pdf. Accessed 10 April 2016.

Rademacher-schulz, C., Schraven, B., \& Mahama, E. S. (2014).

Time matters: Shifting seasonal migration in Northern Ghana in response to rainfall variability and food insecurity. Climate and Development, 6(1), 46-52. https://doi. org/10.1080/17565529.2013.830955.

Rao, N., Lawson, E. T., Raditloaneng, W. N., Solomon, D., Angula, M. N., Rao, N., et al. (2017). Gendered vulnerabilities to climate change: Insights from the semi-arid regions of Africa and Asia. Climate and Development, 1-13. https://doi.org/10.1080/17565529.2017.1372266

Ravera, F., Martın-Lopez, B., Pascual, U., \& Drucker, A. (2016). The diversity of gendered adaptation strategies to climate change of Indian farmers: A feminist intersectional approach. Ambio, 45(3), 335-351. https://doi.org/10.1007/ s13280-016-0833-2.

Reed, M. G. (2017). Understanding the gendered labours of adaptation to climate change in forest-based communities through different models of analysis. In M. Cohen (Ed.), Gender and climate change in rich countries: Work, public policy and action (pp. 199-214). London: Routledge.

Sarr, B., Atta, S., Ly, M., Salack, S., Ourback, T., Subsol, S., et al. (2015). Adapting to climate variability and change in smallholder farming communities: A case study from Burkina Faso, Chad and Niger (CVCADAPT). Journal of
Agricultural Extension and Rural Development, 7(1), 16-27. https://doi.org/10.5897/JAERD2014.0595.

Thompson-Hall, M., Carr, E. R., \& Pascual, U. (2016). Enhancing and expanding intersectional research for climate change adaptation in agrarian settings. Ambio, 45(s3), 373-382. https://doi.org/10.1007/s13280-016-0827-0.

Van Aelst, K., \& Holvoet, N. (2016). Intersections of gender and marital status in accessing climate change adaptation: evidence from rural Tanzania. World Development, 79(2016), 40-50. https://doi.org/10.1016/j.worlddev.2015. 11.003 .

Wrigley-Asante, C. (2011). Women becoming bosses: Changing gender roles and decision making in Dangme West District of Ghana. Ghana Journal of Geography, 3(1), 60-87.

Yaro, A. J. (2010). The social dimensions of adaptation to climate change in Ghana. Washington, DC: The World Bank.

Yiran, G. A. B., \& Stringer, L. C. (2016). Spatio-temporal analyses of impacts of multiple climatic hazards in a savannah ecosystem of Ghana. Climate Risk Management, 14(2016), 11-26. https://doi.org/10.1016/j.crm.2016.09. 003.

Publisher's Note Springer Nature remains neutral with regard to jurisdictional claims in published maps and institutional affiliations. 